\title{
Co-localization of Coagulation Factor $X$ and its Inhibitory System, PZ/ZPI, in Human Endometrial Cancer Tissue
}

\author{
EWA SIERKO $^{1,2}$, EWA ZABROCKA ${ }^{3}$, KRYSTYNA OSTROWSKA-CICHOCKA $^{4}$, \\ PIOTR TOKAJUK ${ }^{1,4}$, LECH ZIMNOCH ${ }^{5}$ and MAREK Z. WOJTUKIEWICZ ${ }^{1,4}$ \\ ${ }^{1}$ Department of Oncology, Medical University, Bialystok, Poland; \\ ${ }^{2}$ Department of Radiotherapy, Comprehensive Cancer Center, Bialystok, Poland; \\ ${ }^{3}$ Department of Medicine, Stony Brook University, Stony Brook, NY, U.S.A.; \\ ${ }^{4}$ Department of Clinical Oncology, Comprehensive Cancer Center, Bialystok, Poland; \\ ${ }^{5}$ Department of Clinical Pathomorphology, Medical University, Bialystok, Poland
}

\begin{abstract}
Background/Aim: Hemostatic system components contribute to cancer progression independently from their roles in hemostasis. It has been shown that protein $Z$ $(P Z) /$ protein $Z$-dependent protease inhibitor (ZPI) inhibit coagulation factor $X(F X)$. The aim of the study was to analyze the expression of PZ/ZPI in relation to the main coagulation factor - FX in human endometrial cancer tissue. Materials and Methods: Immunohistochemical analysis was performed on 21 endometrial cancer specimens employing antibodies against ZPI, PZ and FX. Results: Endometrial cancer cells showed a strong expression of ZPI and PZ and medium expression of $F X$. Normal endometrial tissue showed no expression of ZPI, PZ or FX. Conclusion: Strong expression of $P Z$ and $Z P I$ in endometrial cancer cells suggests a role of these proteins in endometrial cancer.
\end{abstract}

The estimated global incidence of endometrial cancer is approximately 382,000 per year, and nearly 90,000 of women suffering from the disease die yearly, worldwide (1). Gynecological cancer is frequently associated with thromboembolic episodes (TE) (2). The complications (e.g. deep vein thromboembolism, portal vein thrombosis) may precede the diagnosis of the malignant disease and accompany the treatment $(3,4)$. Silent or subclinical venous thromboembolic complications (VTE) occur before treatment in approximately $10 \%$ of patients with endometrial cancer

This article is freely accessible online.

Correspondence to: Ewa Sierko, MD, Department of Oncology, Medical University, 12 Ogrodowa St., 15-027 Bialystok, Poland. Tel: +48 856646786, Fax: +48 856646783, e-mail: ewa.sierko@iq.pl

Key Words: Protein Z, protein Z-dependent protease inhibitor, coagulation inhibitor, factor $X$, endometrial cancer.
(5). Thromboembolic episodes may adversely complicate surgery, external beam radiotherapy, high-dose-rate brachytherapy, chemotherapy or hormonotherapy in gynecological cancer patients (6-10). In advanced stage of endometrial cancer disseminated intravascular coagulation has been reported as well (11). It has been reported that there are changes in coagulation factors prior to any treatment for endometrial cancer, suggesting that the disease may result in a procoagulant state $(12,13)$. Namely, increased levels of fibrinogen, thrombin-antithrombin complex (TAT), and prothrombin fragment $\mathrm{F} 1+2$ have been observed compared to non-cancer individuals $(12,13)$. One of the important steps of coagulation activation in cancer patients has been ascribed to the activation of factor X (FX) (14). Many cancer-specific stimuli have been recognized to trigger its activation, e.g. tissue factor (TF), cancer procoagulant (CP), procoagulant activity and platelet-aggregating activity (PCA/PAA), HLA-DR antigen of MHC (main human compatibility) class, as well as sialic acid residues of mucus glycoproteins, which are synthesized by cancer cells (14, 15). Numerous studies strongly suggest that the hemostatic system components contribute to cancer progression independently from their established roles in hemostasis (14, 16). Factor Xa stimulates cytokine synthesis in effector cells, activates nitrogen oxide synthase, induces adhesion molecule expression as well as the release of growth factors from endothelial cells (ECs) $(17,18)$. It can also activate endothelial protein $\mathrm{C}$ receptor (EPCR) and protease activated receptor-1, which are known to play a role in cancer growth and dissemination (19). FXa, similarly to thrombin, exerts its biologic effects via activation of protease activated receptor- 1 and -2 (PAR-1 and PAR-2) (20-22). The presence of PAR-1 in endometrial cancer tissue has been confined to the highly aggressive, high grade endometrial carcinoma, but not in benign tumors of the endometrium (20). PAR-2 expression, both at the mRNA and protein level, has been 
shown to be significantly increased in uterine endometrial cancers, and to correlate with clinical stage, cancer dedifferentiation as well as with myometrial invasion in comparison to normal endometria (23). Significant correlations between PAR-2 histoscores and mRNA levels with microvessel density in uterine endometrial cancers have been observed suggesting that PAR-2 contributes to endometrial cancer progression via its angiogenic activity (23). In experimental models, FXa has been shown to facilitate cancer cell migration, inhibit apoptosis and contribute to inhibition of metastases $(24,25)$. Thrombin is known to facilitate distant metastases by influencing tumor cell-induced platelet activation, as well as by increasing the adhesive potential of cancer cells and ECs (26-29). Thrombin has also been shown to stimulate cancer cell detachment and migration $(14,30)$ and to facilitate angiogenesis via, among others, inducing synthesis of proangiogenic factor - vascular endothelial growth factor (VEGF) $(27,28)$. VEGF is one of the factors contributing to the aggressive phenotype of endometrial cancer and the pronounced vascular invasion (31). VEGF activity results also in increased permeability of the endothelium $(32,33)$, which facilitates the entry of plasma macromolecules (e.g. fibrinogen) to the extravascular space (33). In turn, fibrin serves as a mechanistic scaffold for proliferating cancer cells and newly formed vessels, a protecting barrier against components of the host's immune system (14), and a reservoir of growth factors $(14,30,32)$.

Recently, it was shown that factor Xa is directly inhibited by the activity of the protein $\mathrm{Z}(\mathrm{PZ}) /$ protein $\mathrm{Z}$-dependent protease inhibitor (ZPI) system (34). PZ serves as a co-factor in the reaction of $\mathrm{FXa}$ inhibition via $\mathrm{ZPI}$, but has no enzymatic function itself (35-37). It has been shown that PZ increases the reaction rate by more than 1,000-fold, efficiently facilitating inhibition of thrombin generation (35). The major role of the ZPI/PZ system is to inhibit the coagulation response prior to the formation of the prothrombinase complex. Protein Z and ZPI circulate in plasma as a complex. In the presence of membrane phospholipids, $\mathrm{PZ}$ interacts with FXa. This facilitates the inhibition of membrane-associated FXa by ZPI (38). ZPI can also be activated by endothelial cell surface glycosaminoglycans and inhibit FXa, which escapes from procoagulant phospholipids (39).

The aim of the study was to analyze the solid phase interaction between PZ/ZPI and the main coagulation factor - FX in human endometrial cancer tissue.

\section{Materials and Methods}

Tissue fragments were obtained at surgical treatment of 21 previously untreated endometrial cancer patients (at clinical stage FIGO II) and fixed in $4 \%$ buffered formalin. Immunohistochemical (IHC) studies were performed on adenocarcinomas of the endometrium (G1 - 6 cases, G2 - 12 cases and G3 - 3 case) and control fragments of respective normal tissues, which were derived from the neoplasm-free surgical margins.

Staining procedures and controls for the avidin - biotin complex technique (ABC) using Vectastain Kits (Vector Laboratories, Burlingame, CA, USA) have been previously described in detail (40). A semi-quantitative analysis of protein expression in cancer cells was carried out according to the Remmele and Stegner scale with our own modification (reported elsewhere) $(41,42)$. The analysis accounted for the diversity of staining observed in our studies $(42,43)$. Both percentage of positively stained cancer cells (A) as well as the intensity of staining (B) are given in numerical values. Immunoreactive score (IRS) was a product of values $A$ and $\mathrm{B}(\mathrm{IRS}=\mathrm{A} \times \mathrm{B})$. Immunoreactive score (IRS) values between 1-4 were interpreted as weak, 5-8 as medium, and 9-12 as strong protein expression $(42,43)$. A monospecific antibody against homogeneous, plasma-derived human PZ was prepared in rabbits, and purified from immune sera by protein A-Sepharose chromatography (44). Specific monoclonal mouse anti-human ZPI IgM (4249.2) was generously provided by Dr. George J. Broze Jr. (Division of Hematology, Barnes-Jewish Hospital, St. Louis, MO, USA) (45), while polyclonal antibodies specific for human FX - by Dr. David Stump (Genentech, South San Francisco, CA, USA) (46). In the control specimens, the primary antibody was omitted from the procedure. In the $\mathrm{ABC}$ immunostaining procedure, antigen staining was detected as a dark brown reaction product.

Visual assessment of protein expression was performed in 10 consecutive high-power fields by two independent observers. The results of IHC studies of endometrial cancer tissues were compared with the results obtained from respective normal endometrium, which were processed simultaneously. The study protocol was approved by the local Ethics Committee of the Medical University in Bialystok, Poland (approval number R-I-002/256/2003) Informed consent was obtained from the patients.

\section{Results}

Strong expression of ZPI (IRS=9) was observed in endometrial cancer cells (Figure 1A). Similarly, endometrial cancer cell bodies were characterized by strong staining intensity of PZ (IRS=9.5) (Figure 1B). Medium expression of coagulation factor $X(I R S=8-9)$ was revealed in association with cancer cells in endometrial cancer specimens (Figure 1C). No differences in intensity of staining for ZPI, PZ and factor X were observed in G1, G2, G3 endometrial cancer (IRS - 9-9.5). No staining for the above-mentioned proteins were observed in normal endometrial tissue (Figure 1D, E and F).

\section{Discussion}

In the cancer patients, venous thromboembolism has been found to be associated with poor prognosis (47). Thrombosis is also the second leading cause of death in this group (16). It is known that blood coagulation can occur not only intravascularly but also extravascularly, within the tumor environment (48). The products of blood coagulation activation have been reported to contribute to angiogenesis and progression at the tumor site as well as distant 


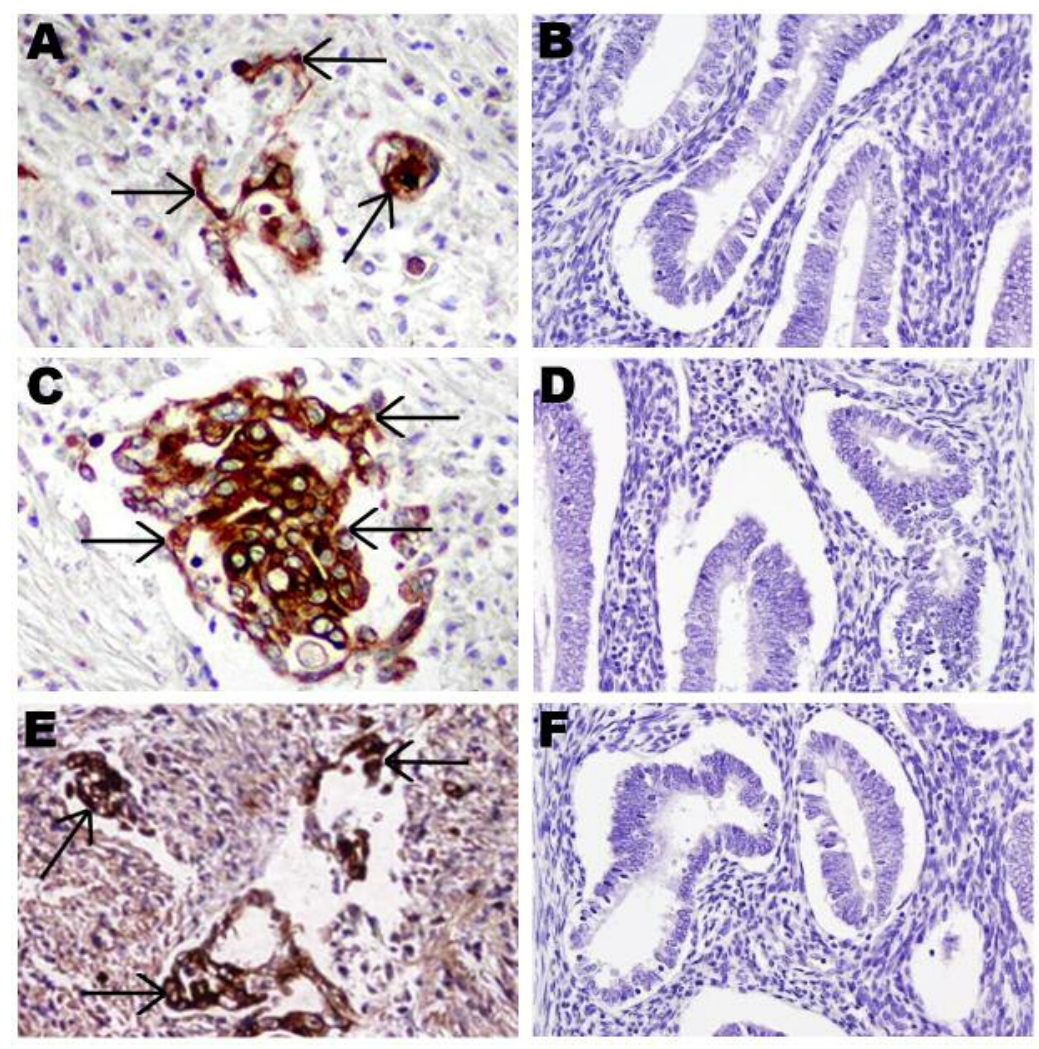

Figure 1. Immunohistochemical staining (brown reaction product) by ABC peroxidase technique, using polyclonal antibodies against protein $Z-$ $P Z-(A)$, coagulation factor $X-F X-(E)$, as well as monoclonal antibody against protein Z-dependent protease inhibitor $-Z P I-(C)$. Arrows show staining of tumor cell bodies in endometrial cancer cells. No staining for PZ $(B), Z P I(D)$ or $F X(F)$ was observed in normal endometrial tissue. Hematoxylin counterstain; original magnification $\times 100$ (Fig. A, B, D, E, F) and $\times 200$ (Figure C).

metastases $(27,28,48)$. However, the exact mechanism of extravascular blood coagulation at tumor sites has not been fully understood. Uccella et al. have reported on the ability of endometrial cancer tissue to synthesize fibrinogen (49) a protein which may increase metastatic capacity of tumor cells (50). Endometrial cancer cells have also been found to express tissue factor after induction by epidermal growth factor, resulting in increased invasive potential (50).

Factor X plays an important role in blood coagulation activation pathway (14). Additionally, it is known to be involved in various biological processes within the tumor environment (48). The present study showed that the expression of factor $\mathrm{X}$ was associated with endometrial cancer cells but not with normal endometrial tissue. The results of previous studies showing the presence of factor $\mathrm{X}$ mRNA in cancer tissue indicate that this coagulation factor can be synthesized by malignant cells (46). Factor X expression has also been observed in gastric and colon cancer cell bodies (46).

Physiologically, increased expression of coagulation factors leads to an increase in the expression of their inhibitors. Factor $\mathrm{X}$ activity is regulated by inhibitory mechanisms, which include tissue factor pathway inhibitor (TFPI), antithrombin, and the PZ/ZPI system (34). However, the data on the PZ/ZPI in endometrial cancer site are obscure. The present study revealed PZ and ZPI expression in endometrial cancer cells, similarly to previous studies that have demonstrated PZ/ZPI presence in breast, colon, gastric and non-small cell lung cancer tissue (44-46, 51-54). These studies have also revealed the presence of PZ/ZPI mRNA at cancer sites, implicating in loco synthesis of these proteins. Additionally, ZPI overexpression has been identified in pancreatic endocrine tumors and their metastases to the liver (55). The presence of both PZ and ZPI, along with FX, in association with endometrial cancer cells may indicate that these proteins modulate coagulation or other processes involved in endometrial cancer pathology at the tumor site.

Except for a putative role in tumor biology, the proteins involved in hemostasis may have the potential to be tumor markers. Gynecological cancer patients have been reported to have significantly higher plasma levels of prothrombin fragment $\mathrm{F} 1+2$ and thrombin-antithrombin complex compared to healthy women (56). Although the synthesis of 
$\mathrm{PZ/ZPI}$ by cancer cells has been reported, it is still unclear if this ectopic expression affects plasma ZP/PZI levels. This may be difficult to investigate in the context of recent findings suggesting that ZPI (but not PZ) may be an acute phase reactant (57). This is reflected in the study by Yoshida et al., which revealed a significant increase in median ZPI levels together with CRP after tumor-related gynecological surgery (58). A significant correlation between ZPI and CRP or fibrinogen has also been found in colorectal and pancreatic cancer patients (59). The same study showed no correlation between PZ levels and CRP or fibrinogen, which may indicate that high levels of $\mathrm{PZ}$ are rather unrelated to the inflammatory state and can be attributed to the ectopic synthesis of PZ by cancer cells. On the contrary, another study has shown lower PZ levels in cancer patients compared to healthy individuals (60). However, all tumors in this study were analyzed collectively, therefore the analysis of PZ levels in individual tumor types is encouraged. Recently, PZ role as a marker of early detection of ovarian cancer has been suggested (61).

Strong expression of PZ and ZPI in association with endometrial cancer cells revealed by the present study suggests a putative role of these proteins in endometrial cancer biology. The intensity of ZP/PZI expression appears not to be influenced by tumor grade. Further studies on PZ/ZPI role in cancer pathology are needed to fully investigate the role of this system in cancer.

\section{Conflicts of Interest}

The Authors declare no conflicts of interest regarding this study.

\section{Authors' Contributions}

Ewa Sierko - concept of the study, supervision, collecting material, performing experiments, interpreting results, writing the manuscript, approval of the text of the manuscript. Ewa Zabrocka - interpreting the results, writing the manuscript, approval of the manuscript; Krystyna Ostrowska- Cichocka - collecting material, performing experiments, interpreting the results, approval of the manuscript; Piotr Tokajuk - performing experiments, interpreting the results, literature searching, approval of the manuscript; Lech Zimnoch interpreting the results, approval of the manuscript; Marek Z. Wojtukiewicz - concept of the study, supervision, approval of the manuscript.

\section{Acknowledgements}

The Authors would like to thank Professor George J. Broze Jr from the Division of Hematology, Barnes-Jewish Hospital, St. Louis, MO, USA for providing us with the antibody against ZPI and Dr. David Stump from Genentech, South San Francisco, California, USA for antibodies specific for human FX. This work was supported by research grant 3 P05B00924 from the Polish Committee of Scientific Research (KBN) to E.S.

\section{References}

1 Bray F, Ferlay J, Soerjomataram I, Siegel RL, Torre LA and Jemal A: Global cancer statistics 2018: GLOBOCAN estimates of incidence and mortality worldwide for 36 cancers in 185 countries. CA Cancer J Clin 68: 394-424, 2018. PMID: 30207593. DOI: $10.3322 /$ caac 21492

2 Cohen A, Lim CS and Davies AH: Venous Thromboembolism in gynecological malignancy. Int J Gynecol Cancer 27: 1970-1978, 2017. PMID: 28930804. DOI: 10.1097/IGC.000000 0000001111

3 Mourra N, Tiret E, Parc Y, de Saint-Maur P, Parc R and Flejou JF: Endometrial stromal sarcoma of the rectosigmoid colon arising in extragonadal endometriosis and revealed by portal vein thrombosis. Arch Pathol Lab Med 125: 1088-1090, 2001. PMID: 11473465. DOI: 10.1043/0003-9985(2001)125< 1088:ESSOTR>2.0.CO;2

4 Toyoda M, Satoh T, Takano K, Sato NO, Oki A, Tsunoda H and Yoshikawa H: Successful diagnosis of thromboembolism before surgery in a woman with clear cell adenocarcinoma of the endometrium. Int J Clin Oncol 10: 444-446, 2005. PMID: 16369752. DOI: $10.1007 / \mathrm{s} 10147-005-0517-6$

5 Satoh T, Matsumoto K, Uno K, Sakurai M, Okada S, Onuki M, Minaguchi T, Tanaka YO, Homma S, Oki A and Yoshikawa H: Silent venous thromboembolism before treatment in endometrial cancer and the risk factors. Br J Cancer 99: 1034-1039, 2008. PMID:18781175. DOI:10.1038/sj.bjc.6604658

6 Fiorica JV, Brunetto VL, Hanjani P, Lentz SS, Mannel R and Andersen W: Gynecologic Oncology Group study. Phase II trial of alternating courses of megestrol acetate and tamoxifen in advanced endometrial carcinoma: A Gynecologic Oncology Group study. Gynecol Oncol 92: 10-14, 2004. PMID:14751131.

7 Noda K, Wada H, Yamada N, Noda N, Gabazza EC, Kumeda K, Okugawa T, Yanoh K, Ito M, Nakano T, Shiku H, Nobori T, Kato $\mathrm{H}$ and Toyoda N: Changes of hemostatic molecular markers after gynecological surgery. Clin Appl Thromb Hemost 6: 197-201, 2000. PMID: 11030524.

8 Petereit DG, Sarkaria JN and Chappell RJ: Perioperative morbidity and mortality of high-dose-rate gynecologic brachytherapy. Int J Radiat Oncol Biol Phys 42: 1025-1031, 1998. PMID: 9869225.

9 Petera J, Odrazka K, Frgala T and Spacek J: External beam radiotherapy and high-dose brachytherapy combined with cisplatin and paclitaxel in patients with advanced cervical carcinoma. Gynecol Oncol 99: 334-338, 2005. PMID: 16023181. DOI: $10.1016 /$ j.ygyno.2005.06.015

10 Jacobson GM, Kamath RS, Smith BJ and Goodheart MJ: Thromboembolic events in patients treated with definitive chemotherapy and radiation therapy for invasive cervical cancer. Gynecol Oncol 96: 470-474, 2005. PMID:15661237. DOI: 10.1016/j.ygyno.2004.10.023

11 Weltermann A, Mitterbauer GJ, Mitterbauer M, Hattey E, Speiser W, Gisslinger H, Knöbl P and Eichinger S: Disseminated intravascular coagulation (DIC) with massive hyperfibrinolysis in metastatic uterine cancer. Observations on the effects on the coagulopathy of various treatments (a case report) (Article in German). Wien Klin Wochenschr 110: 53-57, 1998. PMID: 9531680 .

12 Miodońska J, Ziółkowska E and Uszyński M: Radiotherapy and coagulation system in women with cancer of the genital tract (Article in Polish). Ginekol Pol 71: 406-412, 2000. PMID: 10943040. 
13 Gadducci A, Marrai R, Baicchi U, Gagetti O, Facchini V and Genazzani AR: Prothrombin fragment $\mathrm{F} 1+2$ and thrombinantithrombin III complex (TAT) plasma levels in patients with gynecological cancer. Gynecol Oncol 61: 215-217, 1996. PMID: 8626135. DOI: $10.1006 /$ gyno.1996.0127

14 Zacharski LR, Wojtukiewicz MZ, Costantini V, Ornstein DL and Memoli VA: Pathways of coagulation/fibrinolysis activation in malignancy. Semin Thromb Hemost 18: 104-116, 1992. PMID: 1574711. DOI: $10.1055 / \mathrm{s}-2007-1002415$

15 Cavanaugh PG, Sloane BF, Bajkowski AS, Taylor JD and Honn $\mathrm{KV}$ : Purification and characterization of platelet aggregating activity from tumor cells: copurification with procoagulant activity. Thromb Res 37: 309-326, 1985. PMID: 3975874

16 Falanga A andRickles FR: Pathophysiology of the thrombophilic state in the cancer patient. Semin Thromb Hemost 25: 173-182, 1999. PMID: 10357085. DOI: 10.1055/s-2007-994919

17 Gajdusek C, Carbon S, Ross R, Nawroth P and Stern D: Activation of coagulation releases endothelial cell mitogens. J Cell Biol 103: 419-428, 1986. PMID: 3733873.

18 Schaeffer P, Mares AM, Dol F, Bono F and Herbert JM: Coagulation factor Xa induces endothelium - dependent relaxations in rat aorta. Circ Res 81: 824-828, 1997. PMID: 9351456.

19 Wojtukiewicz MZ, Hempel D, Sierko E, Tucker SC and Honn $\mathrm{KV}$ : Endothelial protein $\mathrm{C}$ receptor (EPCR), protease activated receptor-1 (PAR-1) and their interplay in cancer growth and metastatic dissemination. Cancers (Basel) 11, pii: E5, 12019. PMID: 30626007. DOI: 10.3390/cancers11010051

20 Granovsky-Grisaru S, Zaidoun S, Grisaru D, Yekel Y, Prus D, Beller U and Bar-Shavit R: The pattern of protease activated receptor 1 (PAR1) expression in endometrial carcinoma Gynecol Oncol 103: 802-806, 2006. PMID: 16875721. DOI: 10.1016/j.ygyno.2006.05.048

21 Darmoul D, Gratio V, Devaud H, Lehy T and Laburthe M: Aberrant expression and activation of the thrombin receptor protease-activated receptor- 1 cell induces cell proliferation and motility in human colon cancer cells. Am J Pathol 162: 1503 1513, 2003. PMID: 12707033. DOI: 10.1016/S0002-9440(10) 64283-6

22 Yao XQ, Liu FK, Li JS, Qi XP, Wu B, Yin HL, Ma HH, Shi Q and Zhou XL: Significance of effector protease receptor-1 expression and its relationship with proliferation and apoptotic index in patients with primary advanced gastric adenocarcinoma. World J Gastroenterol 10: 1262-1267, 2004. PMID: 15112339.

23 Jahan I, Fujimoto J, Alam SM, Sato E, Sakaguchi H and Tamaya $\mathrm{T}$ : Expression of protease activated receptor-2 related to angiogenesis in tumor advancement of uterine endometrial cancers. Oncol Rep 17: 345-350, 2007. PMID: 17203172.

24 Versteeg HH, Spek CA, Richel DJ and Peppelenbosch MP: Coagulation factors VIIa and Xa inhibit apoptosis and anoikis. Oncogene 23: 410-417, 2004. PMID: 14724569. DOI: 10.1038/ sj.onc. 1207066

25 Jiang X, Bailly MA, Paneti TS, Capello M, Konigsberg WH and Bromberg ME: Formation of tissue factor-factor VIIa-factor Xa complex promotes cellular signaling and migration of human breast cancer cells. J Thromb Haemost 2: 93-101, 2004. PMID: 14717972.

26 Wojtukiewicz MZ, Tang TG, Ben-Josef E, Renaud C, Walz DA and Honn KV: Solid tumor cells express functional "tethered ligand" thrombin receptor. Cancer Res 55: 698-704, 1995. PMID: 7834643.
27 Tsopanoglou NE, Pipili-Synetos E, and Maragoudakis ME : Thrombin promotes angiogenesis by a mechanism independent of fibrin formation. Am J Physiol 264: C1302-1307, 1993. PMID: 7684562. DOI: 10.1152/ajpcell.1993.264.5.C1302

28 Wojtukiewicz MZ, Hempel D, Sierko E, Tucker SC and Honn KV: Thrombin-unique coagulation system protein with multifaceted impacts on cancer and metastasis. Cancer Metastasis Rev 35: 213-233, 2016. PMID: 27189210. DOI: 10.1007/s10555-016-9626-0

29 Remiker AS and Palumbo JS: Mechanisms coupling thrombin to metastasis and tumorigenesis. Thromb Res 164: S29-S33, 2018. PMID: 29703481. DOI: 10.1016/j.thromres.2017.12.020

30 Bick RL: Coagulation abnormalities in malignancy: a review. Semin Thromb Hemost 18: 353-372, 1992. PMID: 1470924. DOI: $10.1055 / \mathrm{s}-2007-1002575$

31 Mahecha AM and Wang H: The influence of vascular endothelial growth factor-A and matrix metalloproteinase-2 and -9 in angiogenesis, metastasis, and prognosis of endometrial cancer. Onco Targets Ther 10: 4617-4624, 2017. PMID: 29033580. DOI: 10.2147/OTT.S132558

32 Wojtukiewicz MZ, Sierko E, Klement P and Rak J: The hemostatic system and angiogenesis in malignancy. Neoplasia 3: 371-384, 2001. PMID: 11687948.

33 Folkman J: Angiogenesis in cancer, vascular, rheumatoid and other disease. Nature Med 1: 27-31, 1995. PMID: 7584949.

34 Tabatabai A, Fiehler R and Broze GJ Jr.: Protein Z circulates in plasma in a complex with protein Z-dependent protease inhibitor. Thromb Haemost 85: 655-660, 2001. PMID: 11341501.

35 Han X, Fiehler R and Broze GJ Jr.: Characterization of the protein Z-dependent protease inhibitor. Blood 96: 3049-3055, 2000. PMID: 11049983.

36 Han X, Fiehler R and Broze GJ Jr.: Isolation of a protein Zdependent plasma protease inhibitor. Proc Natl Acad Sci USA 95: 9250-9255, 1998. PMID: 9689066.

37 Ichinose A, Takeya H, Espling E, Iwanaga S, Kisiel W and Davie EW: Amino acid sequence of human protein Z, a vitamin K-dependent plasma glycoprotein. Biochem Biophys Res Commun 172: 1139-1144, 1990. PMID: 2244898.

38 Vasse M: The protein Z/protein Z-dependent protease inhibitor complex. Systemic or local control of coagulation? Hamostaseologie 31: 155-158, 160-164, 2011. PMID: 21691673. DOI: $10.5482 /$ ha- 1161

39 Huang X, Rezaie AR, Broze GJ Jr. and Olson ST: Heparin is a major activator of the anticoagulant serpin, protein Z-dependent protease inhibitor. J Biol Chem 286: 8740-8751, 2011. PMID: 21220417. DOI: $10.1074 /$ jbc.M110.188375

40 Hsu S, Raine L and Fanger H: Use of avidin-biotin-peroxidase complex $(\mathrm{ABC})$ in immunoperoxidase techniques: a comparison between $\mathrm{ABC}$ and unlabeled antibody (PAP) procedures. J Histochem Cytochem 29: 577-580, 1981. PMID: 6166661. DOI: $0.1177 / 29.4 .6166661$

41 Remmele W and Stegner HE: Recommendation for uniform definition of an immunoreactive score (IRS) for immunohistochemical estrogen receptor detection (ER-ICA) in breast cancer tissue. Pathologie 8: 138-140, 1987. PMID: 3303008.

42 Sierko E, Wojtukiewicz MZ, Zimnoch L and Kisiel W: Tissue factor pathway inhibitor in breast and colon cancer tissue. Thromb Haemost 103: 198-204, 2010. PMID: 20062932. DOI: 10.1160/TH09-06-0416 
43 Sierko E, Wojtukiewicz MZ, Zimnoch L, Zawadzki R and Kisiel $\mathrm{W}$ : Expression of protein $\mathrm{C}$ (PC), protein $\mathrm{S}$ (PS) and thrombomodulin (TM) in loco in human colorectal cancer. Thromb Res 125: e71-e75, 2010. PMID: 19818470. DOI: 10.1016/ j.thromres.2009.09.011

44 Sierko E, Wojtukiewicz MZ, Zimnoch L, Tokajuk P and Kisiel $\mathrm{W}$ : Protein $\mathrm{Z}$ is present in human breast cancer tissue. Int $\mathrm{J}$ Hematol 93: 681-683, 2011. PMID: 21479979. DOI: 10.1007/ s12185-011-0846-3

45 Sierko E, Wojtukiewicz MZ, Ostrowska-Cichocka K and Zimnoch $\mathrm{L}$ : Protein Z-dependent protease inhibitor (ZPI) is present in loco in human breast cancer tissue. Thromb Haemost 104: 183-185, 2010. PMID: 20458435. DOI: 10.1160/TH09-09-0666

46 Sierko E, Wojtukiewicz MZ, Zimnoch L, Tokajuk P, OstrowskaCichocka K and Kisiel W: Co-localization of protein Z, protein $\mathrm{Z}$-dependent protease inhibitor and coagulation factor $\mathrm{X}$ in human colon cancer tissue: implications for coagulation regulation on tumor cells. Thromb Res 129: e112-118, 2012. PMID: 22424030. DOI: 10.1016/j.thromres.2011.10.027

47 Sørensen HT, Mellemkjaer L, Olsen JH and Baron JA: Prognosis of cancers associated with venous thromboembolism. N Engl J Med 343: 1846-185, 2000. PMID: 11117976. DOI: 10.1056/ NEJM200012213432504

48 Lima LG and Monteiro RQ: Activation of blood coagulation in cancer: implications for tumour progression. Biosci Rep 33: e00064, 2013. PMID: 23889169. DOI: 10.1042/BSR20130057.

49 Uccella S, Cromi A, Vigetti D, Cimetti L, Deleonibus S, Casarin J, Passi A, Riva C and Ghezzi F: Endometrial cancer cells can express fibrinogen: immunohistochemistry and RT-PCR analysis. J Obstet Gynaecol 36: 353-358, 2016. PMID: 26470941. DOI: $10.3109 / 01443615.2015 .1065231$

50 Palumbo JS, Kombrinck KW, Drew AF, Grimes TS, Kiser JH, Degen JL and Bugge TH: Fibrinogen is an important determinant of the metastatic potential of circulating tumor cells. Blood 96: 3302-3309, 2000. PMID: 11071621.

51 Kato S, Pinto M, Carvajal A, Espinoza N, Monsó C, Bravo L, Villalon M, Cuello M, Quest AF, Suenaga A, Brosens JJ and Owen GI: Tissue factor is regulated by epidermal growth factor in normal and malignant human endometrial epithelial cells. Thromb Haemost 94: 444-453, 2005. PMID:11071621.

52 Sierko E, Wojtukiewicz MZ, Zimnoch L, Tokajuk P, OstrowskaCichocka K and Kisiel W: Protein Z/protein Z-dependent protease inhibitor system in loco in human gastric cancer. Ann Hematol 93: 779-784, 2014. PMID: 24158387. DOI: 10.1007/ s00277-013-1941-8

53 Sierko E, Wojtukiewicz MZ, Zimnoch L, Ostrowska-Cichocka K, Tokajuk P, Ramlau R and Kisiel W: Protein Z/protein Zdependent protease inhibitor system in human non-small-cell lung cancer tissue. Thromb Res 129: e92-96, 2012. PMID: 21975032. DOI: 10.1016/j.thromres.2011.09.005
54 Wang H, Huang F, Pan XY, Guan ZB, Zeng WB, Li MJ and Zhang RH: Quantification of protein $\mathrm{Z}$ expression in lung adenocarcinoma tissues and cells. Springerplus 5: 1046, 2016. PMID: 27462494. DOI: 10.1186/s40064-016-2610-x

55 Capurso G, Lattimore S, Crnogorac-Jurcevic T, Panzuto F, Milione M, Bhakta V, Campanini N, Swift SM, Bordi C, Delle Fave $\mathrm{G}$ and Lemoine NR: Gene expression profiles of progressive pancreatic endocrine tumours and their liver metastases reveal potential novel markers and therapeutic targets. Endocr Relat Cancer 13: 541-558, 2006. PMID: 16728581. DOI: $10.1677 /$ erc. 1.01153

56 Gadducci A, Marrai R, Baicchi U, Gagetti O, Facchini V and Genazzani AR: Prothrombin fragment $\mathrm{F} 1+2$ and thrombinantithrombin III complex (TAT) plasma levels in patients with gynecological cancer. Gynecol Oncol 61: 215-217, 1996. PMID: 8626135. DOI: 10.1006/gyno.1996.0127

57 Girard TJ, Lasky NM, Tuley EA and Broze GJ: Protein Z, protein Z-dependent protease inhibitor (serpinA10), and the acute-phase response. J Thromb Haemost 11: 375-378, 2013. PMID: 23205927. DOI: 10.1111/jth.12084

58 Yoshida T, Souri M, Osaki T, Saito S, Meijers JC, Kurachi H and Ichinose A: The plasma levels of protein Z-dependent protease inhibitor increase after gynecological surgery independently of estrogen. Thromb Res 136: 980-986, 2015. PMID:26432651. DOI: 10.1016/j.thromres.2015.09.020

59 Doat S, Borgel D, François JH, Bianchini E, Botton J, François D, Mitry E and Vasse M: Unbalance between plasma levels of Protein $\mathrm{Z}$ and protein Z-dependent inhibitor in patients with colorectal and pancreatic cancer: a pilot study. Thromb Res 133: 299-300, 2014. PMID: 24315319. DOI: 10.1016/j.thromres.2013.11.015

60 Shang Y, Pan XY, Ding CP, Yang XM, Cai XY, Ding Y and Zhang RL: Clinical significance of protein $\mathrm{Z}$ detection in patients with malignant tumors. Ai Zheng 24: 1144-1147, 2005. PMID:16159443.

61 Russell MR, Walker MJ, Williamson AJ, Gentry-Maharaj A, Ryan A, Kalsi J, Skates S, D'Amato A, Dive C, Pernemalm M, Humphryes PC, Fourkala EO, Whetton AD, Menon U, Jacobs I and Graham RL: Protein Z: a putative novel biomarker for early detection of ovarian cancer. Int J Cancer 138: 2984-2992, 2016. PMID: 26815306. DOI: 10.1002/ijc. 30020

Received March 9, 2019

Revised April 2, 2019

Accepted April 5, 2019 